\title{
Daria Janiszewska, Wojna domowa w Rzymie w latach 193-197, Wydawnictwo Poznańskie, Poznań 2010, ss. 231
}

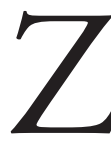

wycięstwo Oktawiana nad Markiem Antoniuszem nie tylko kończyło okres późnej republiki w dziejach antycznego Rzymu, ale przede wszystkim położyło kres długotrwałej wojnie domowej. Można stwierdzić, że zwycięstwo Oktawiana w wojnie domowej stanowiło podwaliny nowego ustroju, zwanego pryncypatem. Utworzenie nowego ładu i porządku wprawdzie przerwało polityczne i zbrojne konflikty, jakie były toczone w okresie późnej republiki, lecz w dłuższej perspektywie dziejowej nie wytrzymało próby czasu i nie zapobiegło walkom wewnętrznym w Imperium Romanum. W okresie dwóch pierwszych stuleci po narodzeniu Chrystusa brak uregulowanej zasady sukcesji władzy cesarskiej, ambicje dowódców wojskowych oraz siła ich armii doprowadziły dwukrotnie, w wyniku wojen domowych, do osiągnięcia purpury cesarskiej przez wybitne jednostki. Wojna domowa z lat 68-69 wyłoniła zwycięzcę w osobie Wespazjana, a wojna domowa z lat 193-197 - w osobie Septymiusza Sewera.

O ile „Rok Czterech Cesarzy” (lata 68-69) został gruntownie opracowany w literaturze naukowej ${ }^{1}$, o tyle konflikt zbrojny między Septymiuszem Sewerem, Dydiuszem Julianem, Pescenniuszem Nigrem i Klodiuszem Albinem, czyli pretendentami do tronu cesarskiego po upadku dynastii Antoninów, nie doczekał się dotychczas odrębnego opracowania w formie monografii. Daria Janiszewska, pracownik naukowy Zakładu Archeologii i Historii Starożytnej Uniwersytetu Zielonogórskiego, podjęła się próby opracowania tego tematu, wypełniając tym samym lukę istniejącą nie tylko w polskiej, ale również w obcojęzycznej literaturze przedmiotu. Autorka w swej pracy - składającej się z pięciu rozdziałów - omawia, opierając się na na różnego rodzaju źródłach, historię wojny domowej z lat 193-197. Oprócz źródeł narracyjnych Janiszewska wykorzystuje - szczególnie cenne w badaniach prozopograficznych - źródła epigraficzne, jak również źródła numizmatyczne oraz dzieła sztuki, które są bardzo istotne dla rozważań nad propagandą i ideologią władzy cesarskiej. Wykorzystanie źródeł różnego typu wynika nie tylko z prawideł warsztatu historyka starożytności, co wydaje się oczywiste, ale jest spowodowane chociażby istnieniem wyraźnego niebezpieczeństwa związanego z faktem pisania historii przez współczesnych zwycięskiemu Sewerowi starożytnych pisarzy, Herodiana

1 Zob. P. A. L. Greenhalgh, The Year of the Four Emperors, London 1975; K. Wellesley, The Year of the Four Emperors, London 2000; G. Morgan, 69 A. D. The Year of Four Emperors, Oxford-New York 2006. 
i Kasjusza Diona, którzy odmalowali obraz współczesnych im wydarzeń z perspektywy wytworzonej przez cesarzy dynastii Sewerów. Dodatkowo pewną trudność sprawia opis tych wydarzeń zamieszczony w późnoantycznej Historii Augusta. Autorka monografii nie przedstawia wojny domowej z końca II wieku wyłącznie jako konfliktu, którego głównym aktorem jest zwycięski Septymiusz Sewer, lecz wnikliwie opisuje także jego politycznych konkurentów, których obraz - właśnie dzięki analizie źródeł różnego typu, nie zaś tylko tych stricte narracyjnych - mógł zostać wzbogacony o wątki nieobecne dotąd w naukowej refleksji i zmieniające nasz sposób myślenia o tych postaciach.

W rozdziale pierwszym (s. 20-62) D. Janiszewska przedstawia tło wydarzeń politycznych, które nastąpiły po 31 grudnia 192 roku, czyli po zamordowaniu ostatniego cesarza z dynastii Antoninów - Kommodusa. Autorka opisuje przebieg wydarzeń z lat 193-197, głównych bohaterów, ich drogi awansu oraz teatr działań zbrojnych. Dzięki prześledzeniu karier wiemy na przykład, że Sewer współpracował z Nigrem i Albinem podczas usuwania band dezerterów (Bellum Desertorum) w Galii w latach 185-186 (s. 42). Rozdział ten stanowi swego rodzaju wstęp do dalszych rozważań. Drugi rozdział (s. 63-88) przedstawia tło polityczne przewrotu na szczycie władzy w roku 193 oraz politykę personalną Sewera. Spisek na życie Kommodusa, udział w nim spiskowców, rola Pertynaksa to główne wątki poruszone przez autorkę na początku rozdziału. Janiszewska bada również udział późniejszych rywali w walce o purpurę cesarską - Septymiusza Sewera, Pescenniusza Nigra i Klodiusza Albina w wydarzeniach, które nastąpiły po śmierci Pertynaksa i przejęciu władzy przez Dydiusza Juliana. Niezwykle cenny wydaje się opis wojskowego zaplecza wojny domowej zawierający zestawienie poszczególnych legionów, które opowiedziały się po stronie wojujących pretendentów do władzy (s. 71-73). Ostatnia część tego rozdziału wykorzystująca metodę prozopograficzną ukazuje przemyślaną strategię personalną Sewera, która wydaje się podstawowym filarem jego politycznego sukcesu. Dzięki ustaleniom tego typu badań autorka potwierdziła chociażby niesłuszność koncepcji prezentowanej przez badaczy przełomu XIX i XX wieku, wedle której Sewer stworzyt wokót siebie „afrykańskie stronnictwo”, złożone z ludzi pochodzenia afrykańskiego (s. 87). W tym miejscu warto nadmienić, że w Polsce badania prozopograficzne elit doby Sewerów są prowadzone również przez Danutę Okoń z Uniwersytetu Szczecińskiego, która senatorom z okresu Sewerów poświęciła rozprawę habilitacyjną․ W trzeciej części (s. 89-109) Janiszewska prezentuje skutki polityczne wojny domowej, jej konsekwencje dla warstwy senatorskiej (np. proskrypcje), która podczas konfliktu wewnętrznego nie prezentowała jednego, lo-

2 D. Okoń, Severi et senatores. Polityka personalna cesarzy dynastii Sewerów wobec senatorów w świetle badań prozopograficznych (193-235 r. n.e.), Szczecin 2009. 
jalnego stanowiska politycznego. Septymiusz Sewer podjął działania nie tylko w tej sferze. Lojalność prowincji oraz miast wobec pretendentów do władzy w wojnie domowej była częstokroć kluczowa dla przebiegu działań zbrojnych. Sposób potraktowania Antiochii, Laodycei, Bizancjum czy też Lugdunum przez zwycięskiego Sewera dobrze ilustruje znaczenie osobistych sympatii i antypatii cesarza. Badaczka w tym rozdziale opisuje także metody zdobywania popularności wśród żołnierzy. Sewer pozwalał żołnierzom nie tylko na łupienie pokonanych miast, ale również podwyższał stipendium. Doprowadził także do reformy gwardii pretoriańskiej i nadania żołnierzom ius conubii. Ciekawym przejawem zdobywania popularności wśród żołnierzy było nadawanie wiernym legionom tytułów honorowych (np. fidelis constans) oraz uczynienie swej żony, Julii Domny - mater castrorum. Ten ostatni - mający niewątpliwie religijny charakter - aspekt, poświadczony za pomocą wyrytego w inskrypcji czy wybitego na monecie tytułu, stanowił także narzędzie propagandy, mające na celu umocnienie wierności wobec panującej dynastii. Kolejny, czwarty rozdział (s. 110-157) poświęcony jest właśnie propagandzie, wizerunkowi oraz ideologii głównych uczestników wojny. Autorka stara się wykazać, że konkurenci do władzy w latach 193-197 korzystali z narzędzi propagandy kształtowanych już od panowania pierwszego pryncepsa. Poprzez cenne analizy filologiczne pojęć używanych przez antycznych historyków na określenie wojny domowej autorka przedstawia stosunek ówczesnych kronikarzy wywodzących się z senatu i elit rzymskich do relacjonowanych wydarzeń. Sposób, w jaki kreowano wydarzenia, miał ogromny wpływ na opinię publiczną doby Sewerów. Dodatkowe analizy ówczesnego mennictwa przeprowadzone przez badaczkę nie tylko uzupełniają relacje narracyjne, ale również pozwalają na przedstawienie koncepcji rządów przeciwników politycznych. W ten sposób zostały zaprezentowane obraz i ideologia władzy Dydiusza Juliana oraz Pescenniusza Nigra. W przypadku Klodiusza Albina czytelnik może również śledzić zmianę programu politycznego, co wynika z zachowanych monet wybijanych w Rzymie i Lugdunum. Monety w przypadku Albina są o tyle ważne, że oprócz ideologii władzy potwierdzają relację Historii Augusta o pochodzeniu namiestnika Brytanii z afrykańskiego Hadrumentum. Janiszewska wykazuje również, że strategia autoprezentacji Septymiusza Sewera była wszechstronna i obejmowała wszystkie ówczesne środki przekazu. Autorka udowadnia, że Sewer poprzez mennictwo, rzeźbę, inskrypcje czy też święta państwowe starał się zaprezentować wizję własnego panowania. Deifikacja Helwiusza Pertynaksa i wejście Sewera do rodu Antoninów jako syna Marka Aureliusza i brata Kommodusa były sposobem wyrażenia legitymizacji władzy, kontynuacji polityki poprzednich cesarzy oraz utrzymania autorytetu. W ostatnim, piątym rozdziale (s. 158-177) Janiszewska przedstawia wizerunek Septymiusza Sewera i jego zmiany w historiografii XIX i XX wieku. Ocena tego wizerunku nigdy nie była jednakowa wśród uczonych. Obraz uzurpatora 
zaprezentowany przez Alfreda von Domaszewskiego pod koniec XIX wieku jest zupełnie inny od późniejszej oceny dokonanej przez Erica Birleya czy też Aristide Calderiniego. Janiszewska swe rozważania dotyczące wizerunku Sewera w historiografii kończy na przywołaniu artykułu Masona Hammonda ${ }^{3}$ z 1940 roku (s. 162). Zastanawiające jest, dlaczego badaczka w tej części pracy nie przedstawia opinii nowszej historiografii, której przedstawicielami są chociażby Anthony R. Birley i Tadeusz Kotula. Dalej autorka opisuje także relacje władcy z senatorami w nowych okolicznościach związanych z końcem wojny domowej. Ciekawą prezentacją poglądów elit rzymskich na sposób sprawowania władzy przez Sewera są przywołane przez autorkę: Mowa Agryppy i Mowa Mecenasa autorstwa Kasjusza Diona oraz Żywot Apolloniusza z Tyany napisany przez Flawiusza Filostratosa. W dalszej części kończącego pracę rozdziału zostały opisane: rola armii jako czynnika umacniającego władzę Sewera, sposoby odwołania się Sewera do ideologii wybitnych poprzedników, którzy również zdobyli władzę w wyniku wojny domowej, tj. do Oktawiana Augusta i Wespazjana, oraz aspekty religijne pierwszych lat rządów Sewera. W uwagach końcowych Janiszewska określa Sewera jako monarchę wojskowego, którego zbiurokratyzowany system współrządzenia państwem był oparty na profesjonalnych jurystach i silnej władzy cesarza. Całość pracy uzupełniają dwa dodatki w postaci kalendarium wojny domowej z lat 193-197 oraz zestawienia legionów, które opowiedziały się po stronie Sewera, Nigra i Albina podczas tego konfliktu. Zaletą pierwszego dodatku jest umożliwienie czytelnikowi dokładnego śledzenia wydarzeń z okresu wojny domowej. Autorka przywołuje częstokroć daty dzienne, które można było ustalić m.in. dzięki kalendarzowi wojskowych uroczystości - Feriale Duranum, czy też zapisaniu ich w treści papirusów. Dzięki treści jednego z nich wiemy na przykład, że Egipt przyłączył się do zwycięskiego Sewera 13 lutego 194 roku (s. 52, przyp. 290). Drugi dodatek, mający formę tabeli, w przejrzysty sposób prezentuje czytelnikowi nie tylko nazwę konkretnego legionu, ale również prowincję i obóz, z którego pochodziła dana jednostka wojskowa. Na końcu książki znajduje się wykaz skrótów oraz bibliografia, na którą składa się ponad czterysta opracowań. Wartość pracy znacznie podnoszą zamieszczone w niej ilustracje ukazujące monety, popiersia cesarzy oraz dzieła sztuki.

Badacz dziejów starożytnych spotyka się często z problemem opisywania antycznej rzeczywistości za pomocą współczesnej terminologii. Stosowanie przez autorkę pojęć, takich jak „opinia publiczna” czy też „stan wojenny” wydaje się zasadne (s. 110, 176), lecz posługiwanie się terminem "generałowie” (np. s. 70), który stosuje Janiszewska na określenie starożytnych dowódców wojskowych, jest w mym

${ }^{3}$ Chodzi o artykuł M. Hammonda, Septimius Severus, Roman Bureaucrat, „Harvard Studies in Classical Philology", 51, 1940, s. 137-173. 
odczuciu bezpodstawne. Pewien redakcyjny błąd, nierzutujący jednak na wysoką ocenę recenzowanej pracy, stanowi podawanie przez autorkę stron (s.), a nie szpalt (szp.) czy kolumn (col.) w przypadku powoływania się na hasła zamieszczone w Realencyclopädie der classischen Altertumswissenschaft (np. s. 64, przyp. 4). Praca mimo swych niekwestionowanych walorów naukowych może być również przydatna czytelnikowi mniej zorientowanemu w tej tematyce. Oryginalne cytaty z dzieł klasycznych zostały podane także w tłumaczeniu polskim, co dla czytelnika nieobeznanego z łaciną czy z greką jest niezwykle ważne. Książka jest napisana językiem przystępnym i potoczystym. Autorka przedstawia dojrzałe tezy i pogłębione wnioski. Układ pracy oraz dobór poszczególnych rozdziałów dokonane przez autorkę wydają się właściwe i czynią pracę wszechstronną. Wykorzystanie różnego rodzaju źródeł oraz oparcie się na literaturze światowej to ogromne zalety recenzowanej książki. Autorka w sposób wyczerpujący prezentuje historię wojny domowej z końca II wieku, oferując nie tylko gronu specjalistów, ale również szerszemu kręgowi czytelników pozycję niezwykle interesującą, dotychczas nieobecną w literaturze naukowej.

Karol Kłodziński (Toruń) 